\title{
Managing palaeontological heritage: a brief overview of policy and practice in England
}

\author{
Jonathan G. LARWOOD \& Colin D. PROSSER
}

Natural England, Unex House, Bourges Boulevard, Peterborough, PE1 1NG, United Kingdom

* Corresponding author

Larwood, J.G. \& Prosser, C.D. 2019. Managing palaeontological heritage: a brief overview of policy and practice in England. [Gestión del patrimonio paleontológico: una breve revisión de la política y la práctica en Inglaterra]. Spanish Journal of Palaeontology, 34 (1), 57-64.

\begin{abstract}
Fossil collecting for scientific and educational reasons, as well as to support natural curiosity, has taken place in England since at least the late eighteenth century. It was not, however, until the late nineteenth, and particularly the mid-twentieth century, that site-based conservation of palaeontological heritage, and the management of collecting, was established. This paper provides a brief overview of the development of the policy and practice of palaeontological heritage management in England. It includes an outline of the establishment of national legislation, and a summary of the practical approaches to managing palaeontological sites and the collection of fossils that have been adopted. A number of examples are used to illustrate the application of this approach in different circumstances, including the coastal and quarrying environments.
\end{abstract}

Keywords: Palaeontology, fossil collecting, geoconservation, legislation, site management.

\section{RESUMEN}

La recolección de fósiles, tanto con objetivos científicos y educativos como para satisfacer la curiosidad natural, ha tenido lugar en Inglaterra desde al menos el final de siglo XVIII. Sin embargo, no fue hasta finales del siglo XIX, y especialmente hasta mediado el siglo XX, cuando se establecieron las bases para la conservación del patrimonio paleontológico y la gestión de la recolección. Este artículo realiza una breve revisión del desarrollo de las políticas y prácticas empleadas en la gestión del patrimonio paleontológico en Inglaterra. Incluye un esbozo del establecimiento de la legislación nacional, y un resumen de las aproximaciones prácticas que han sido adoptadas para la gestión de los yacimientos paleontológicos y de las colecciones de fósiles. Se utilizan varios ejemplos para ilustrar la aplicación de esta forma de gestión en diferentes circunstancias, incluyendo los ambientes costeros y las canteras.

Palabras clave: Paleontología, recolección de fósiles, geoconservación, legislación gestión de yacimientos. 


\section{INTRODUCTION}

The importance of palaeontology, including palaeontologically rich sites, the collections made and the role of the collector (both 'amateur' and 'professional'), has long been recognised in the United Kingdom (UK). Fossil collecting became increasingly important in the late eighteenth and early nineteenth century (Rudwick, 1976) with a growing curiosity in the origin of fossils and the role they could play in understanding the history of life and the world around us. The geologist William Smith (1769-1839) and fossil collector Mary Anning (1799-1847) illustrate this in both an England and global context.

William Smith, through his work as an engineer and land surveyor, developed a deep understanding of the relationship between rock sequences and fossils. He observed that the "same strata were found always in the same order of superposition and contained the same peculiar fossils" (Phillips, 1844), through which he established the principle we now know as biostratigraphy. Understanding this relationship enabled Smith, in 1815, to produce the first large scale geological map in the world " $A$ delineation of strata of England and Wales, with part of Scotland" and the later publication of "Strata Identified by Organized Fossils" (London 1816-1819) establishing the importance of fossils in biostratigraphy and geological field mapping. These principles remain as important today as they were ground breaking then and led to Smith being known as the 'Father of English Geology'.

Perhaps the most famous fossil collector (globally), even today, is Mary Anning (Torrens, 1995). Born in Lyme Regis, Dorset, she collected and sold fossils from the Lower Jurassic coastline (now part of the Jurassic Coast World Heritage Site www.jurassiccoast.org). She established a working relationship with a number of the prominent geologists of her time, and her fossils are today found in museums throughout the world. She was responsible for first discoveries including ichthyosaur, plesiosaur and pterosaur vertebrate fossils, and for establishing the role of the 'amateur' collector in geological science. This tradition continues today, exemplified through the work of Steve Etches, whose fossil collection from the Late Jurassic Kimmeridgian sequence of Kimmeridge Bay, Dorset, is now housed in the purpose built Museum of Jurassic Marine Life www.theetchescollection.org/home (Noè et al., in press).

Although the importance of palaeontological heritage was well established, it is not until the late nineteenth century, and with real impetus, the mid twentieth century, that the first action was taken to conserve this resource.

\section{PALAEONTOLOGY - CONSERVATION AND LEGISLATION}

The first example in England of site based geological (and palaeontological) conservation occurred at Wadsley, in Sheffield. Here, Carboniferous stigmarias were discovered in 1874 (Sorby, 1875; Thomas, 2005; Prosser, 2010) and then conserved, in situ, in specially constructed buildings. It is not until 1949, however, that Great Britain enacted national nature conservation legislation, which included provision for the conservation of any area of land of special interest because of its 'flora, fauna, geological or physiographical features'. Since then, government conservation agencies have been required to identify and seek to protect sites of geological, including palaeontological, importance (Prosser, 2008, 2013). This legislation, although modified over time, still applies today: where land is of national geological importance it can be designated as a Site of Special Scientific Interest (SSSI) and where it is managed primarily for nature conservation, declared as a National Nature Reserve (NNR). SSSI designation does not affect the ownership, but seeks to protect the special geological interest by restricting activities that can take place on the land without first consulting the appropriate conservation agency (Prosser, 2008).

Sites suitable for designation as SSSIs, or declaration as NNRs, are identified through a systematic and rigorous audit and selection process known as the Geological Conservation Review (GCR) (Ellis et al., 1996; Ellis, 2011; Brown et al., 2018). This audit involves geoscientists and conservation agency staff identifying those sites considered of national importance across the broad range of geological subjects, including palaeontology. GCR sites only receive protection when they go through the legal process of being designated as an SSSI, or declared as an NNR, both of which involve consultation with the relevant landowners. In England there are approximately 1200 geological SSSIs of which 154 are designated specifically for their palaeontology, and a further 700 for their stratigraphical interest and associated fossil invertebrate fauna.

Once designated as a palaeontological SSSI, development proposals or activities (such as coastal protection or quarry infill) that may damage or obscure the palaeontological interest features must be subject to consultation and require the consent of the appropriate government conservation agency (in England this is Natural England). This provides the opportunity to suggest modifications to avoid or reduce damage, or where damage is unavoidable, to object to the proposals or activity taking place. In many cases, a compromise can be reached that retains the palaeontological interest and allows the proposed activities to take place. Designation also gives some control over activities such as fossil collecting, especially where the resource is finite, and potentially at 
risk from over collecting (King \& Larwood, 2001). It is important to note, however, that fossils are owned either by the landowner (or the owner of the mineral rights) and designation as a protected area (such as a SSSI) does not change ownership rights (Taylor \& Harte, 1991).

In addition to SSSIs and NNRs, which provide the primary means of delivering palaeontological conservation in England, there are also approximately 3500 Local Geological Sites (Larwood, 2010a; Whiteley \& Browne, 2013), many of which have a paleontological interest. Although lacking legal protection, these locally important sites are designated, recorded in local plans, and taken into account by local planning authorities when considering development proposals. Also, England's internationally important geoheritage sites, including the Jurassic Coast World Heritage Site and English Riviera and North Pennines UNESCO Global Geoparks, rely on the SSSIs and Local Sites that fall within them, as the basis for conserving the internationally important features for which they are recognised (Brown et al., 2018).

\section{PALAEONTOLOGY - MANAGING SITES AND COLLECTING}

Prosser et al. (2018) discuss the principles and practice of geosite conservation through a structured framework that relates site selection, an analysis of conservation needs (related to site use, character, and sensitivity) and conservation delivery (related to responding to threat, and establishing and delivering management).

\section{MANAGING SITES}

In the context of palaeontological sites, management of threats (such as coastal protection, the infill and restoration of quarries, or the degradation of protected sections) can be dealt with through a legislative/planning route (for example the agreement of planning conditions or restrictions) or establishing agreed management (particularly where ongoing management and removal of obscuring vegetation and scree build-up is needed).

Frogden Quarry SSSI in Dorset, southern England (Fig. 1), illustrates the role of legislative protection, planning conditions and agreed management (Larwood \& Chandler, 2016). This nineteenth century quarry was designated as a SSSI in 1954 for its sequence of Middle Jurassic (Aalenian to Bajocian) Inferior Oolite limestone and its particularly diverse and well preserved fossil invertebrate fauna (notably ammonites). Having been disused for many years, the quarry was reopened on a small scale in 2000, and in
2005 planning permission was granted for the extraction of building stone (Fig. 1a). SSSI status enabled planning conditions relating to the site's palaeontological interest to be agreed. These have facilitated on-going research (e.g., Chandler et al., 2014) through the establishment of a recording and collecting scheme (Figs 1b-1c), and the requirement to retain final restoration sections displaying the designated geological features. Whilst a requirement of the planning system, the success of this initiative has very much been a result of the support and collaborative approach of the land owner, working with geological specialists.

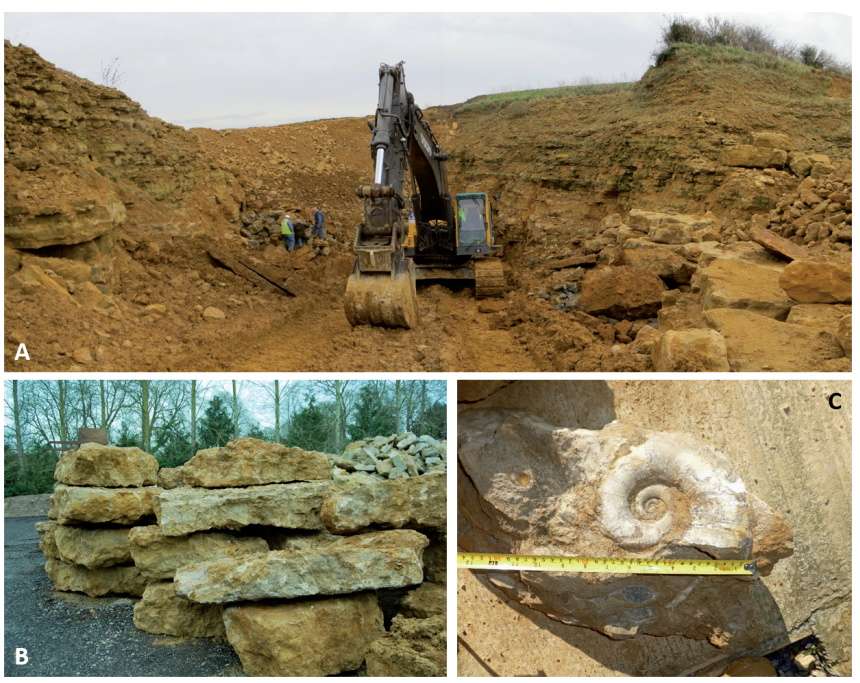

Figure 1. a) Building stone extraction at Frogden Quarry SSSI, Dorset. The quarry floor marks the top of the productive fossil beds and the working face is the Sherborne Limestone Member and source of Sherborne building stone. b) Blocks of Inferior Oolite limestone from Frogden Quarry stored at the nearby Castle Yard. The blocks are marked with white paint indicating the top (bedding plane) surface and are awaiting inspection for fossils prior to cutting for building stone. c) Lower Bajocian Lytoceras $\mathrm{sp}$, a well preserved ammonite from bed 4 of the Humphriesianum Zone (Chandler et al., 2014). (Photographs: Robert Chandler).

Other examples include the modification of coastal protection at Lyme Regis within the Jurassic Coast WHS (Prosser et al., 2018). Here, planning consultation (related to the WHS and underpinning SSSI designation) was designed to ensure that fossiliferous beds remained accessible on completion of the engineering scheme, and a watching brief to record new fossil material during construction was undertaken (Fig. 2a). Road development and modification can offer similar opportunities. Farley Dingle SSSI (a disused railway cutting near Wenlock in Shropshire), designated for exposures of the Silurian 

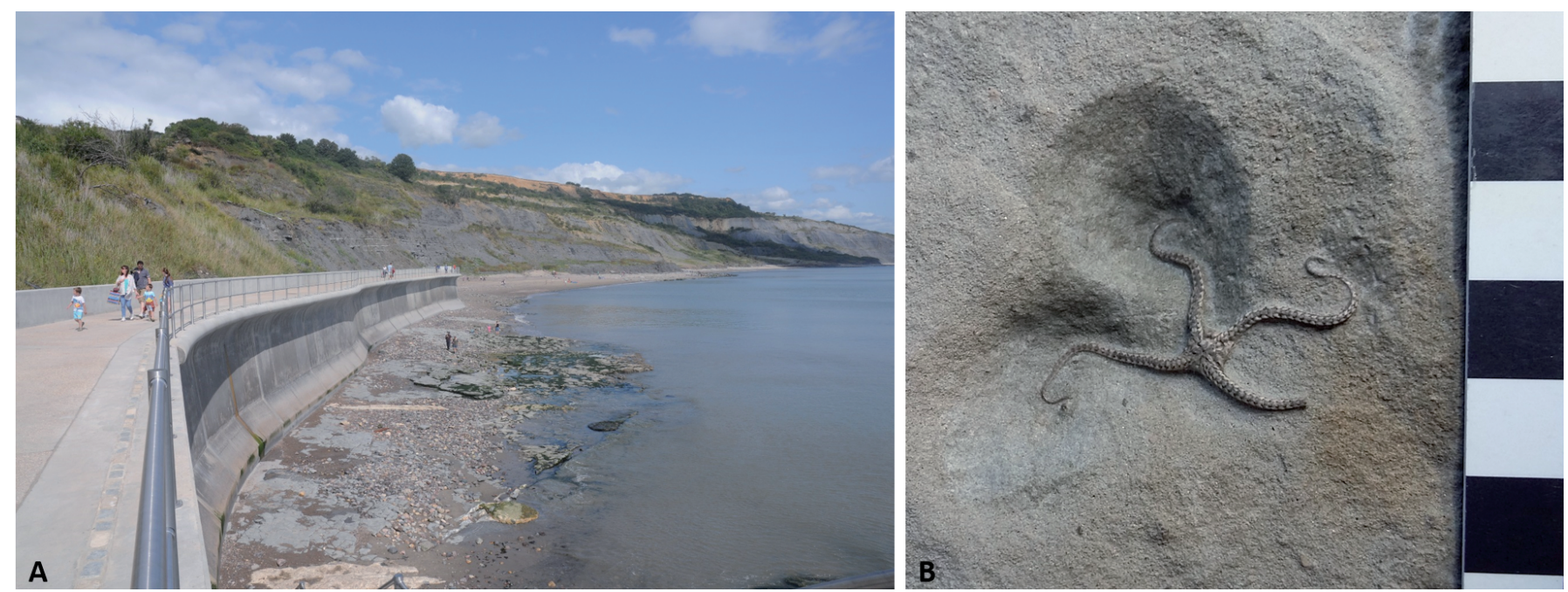

Figure 2. a) Lyme Regis, Dorset, looking eastwards towards Charmouth. The coastal protection scheme here has been modified to retain accessible fossil-rich foreshore exposures. (Photograph: Richard Edmonds). b) Fossil brittle star recorded (ref. 338) as part of the West Dorset Collecting Code and Recording Scheme. The specimen, Palaeocoma egertoni, from the Lower Jurassic (Pliensbachian) Starfish Bed exhibits unusual mutation (only 4 legs). With the support of the Jurassic Coast Trust the specimen was acquired by the local Bridport Museum. Scale bar in cms. (Photograph: Jonathan Larwood).

Wenlock Series (including fossil brachiopod and trilobite fauna), was threatened by road re-routing of a nearby road. Following statutory consultation, the road was re-designed to encompass new permanent terraced sections, significantly enhancing the level of available and accessible fossiliferous exposure (Larwood \& Markham, 1996; Prosser et al., 2006).

Where the encroachment of vegetation and build-up of scree obscure palaeontological sections, establishing and agreeing a management plan is important. For example, the disused sand pits of Sutton Knoll (Rockhall Wood SSSI) in Suffolk, eastern England, expose marine Red Crag (Pleistocene) and Coralline Crag (Pliocene) sediments (Fig. 3). Overtime, the faces have collapsed and vegetation has concealed the sections. Collaboration with the local geology volunteer group (GeoSuffolk) and a formal management agreement with the landowner have provided the resources to maintain, re-expose sections, and establish new paths throughout the site (Hall, 2017).

Alternative approaches include temporary burial of the fossil resource, for example the Carboniferous stigmarias at Wadsley in Sheffield (Prosser, 2010) are now temporarily buried, as the original Victorian protective buildings have been removed, and dinosaur trackways in an active Oxfordshire quarry SSSI, once exposed and recorded, are temporarily reburied (Evans, 2010). Also, moulds (and casts) have been taken of fossiliferous bedding plane surfaces, most notably Precambrian trace fossils in the Charnwood area of Leicestershire, where again there is risk of weathering and damage from illegal collecting or vandalism (Larwood, 2010b; Williams \& Edwards, 2013).

\section{MANAGING COLLECTING}

In the UK (and more widely), there is a broad consensus that palaeontological collecting, as long as it is carried out in a sustainable and responsible manner, is an essential component of geological site use and successful geological conservation (Crowther \& Wimbledon, 1988; Norman, 1992; Bassett et al., 2001; Larwood \& King, 2001; ProGEO, 2011; Wimbledon \& Smith-Meyer, 2012; Page, 2018).

Although legislation provides an effective means of reducing damage to palaeontological features resulting from planned development, this approach is not always suitable to manage fossil collecting, especially where sites are located in remote areas where collecting is difficult to control, and does not apply to areas outside protected sites. For this reason, Natural England has sought to educate rather than just legislate, and has worked in partnership with landowners, fossil collectors, geological societies and museums to develop collecting principles, guidelines, and codes of practice (for example the Geologists' Association's Field Codes (www.geologistsassociation.org.uk/codesofconduct/) and Townley \& Larwood, 2012a, 2012b).

The principles of responsible collecting developed by Natural England in consultation with relevant stakeholders (Townley \& Larwood, 2012a) emphasise the importance of having permission to collect, restricting the scale and volume of collecting, making a record of material collected, and carefully managing and looking after both the collecting site and collected material - all of which are standard, best field practice. In managing collecting, it is important to 

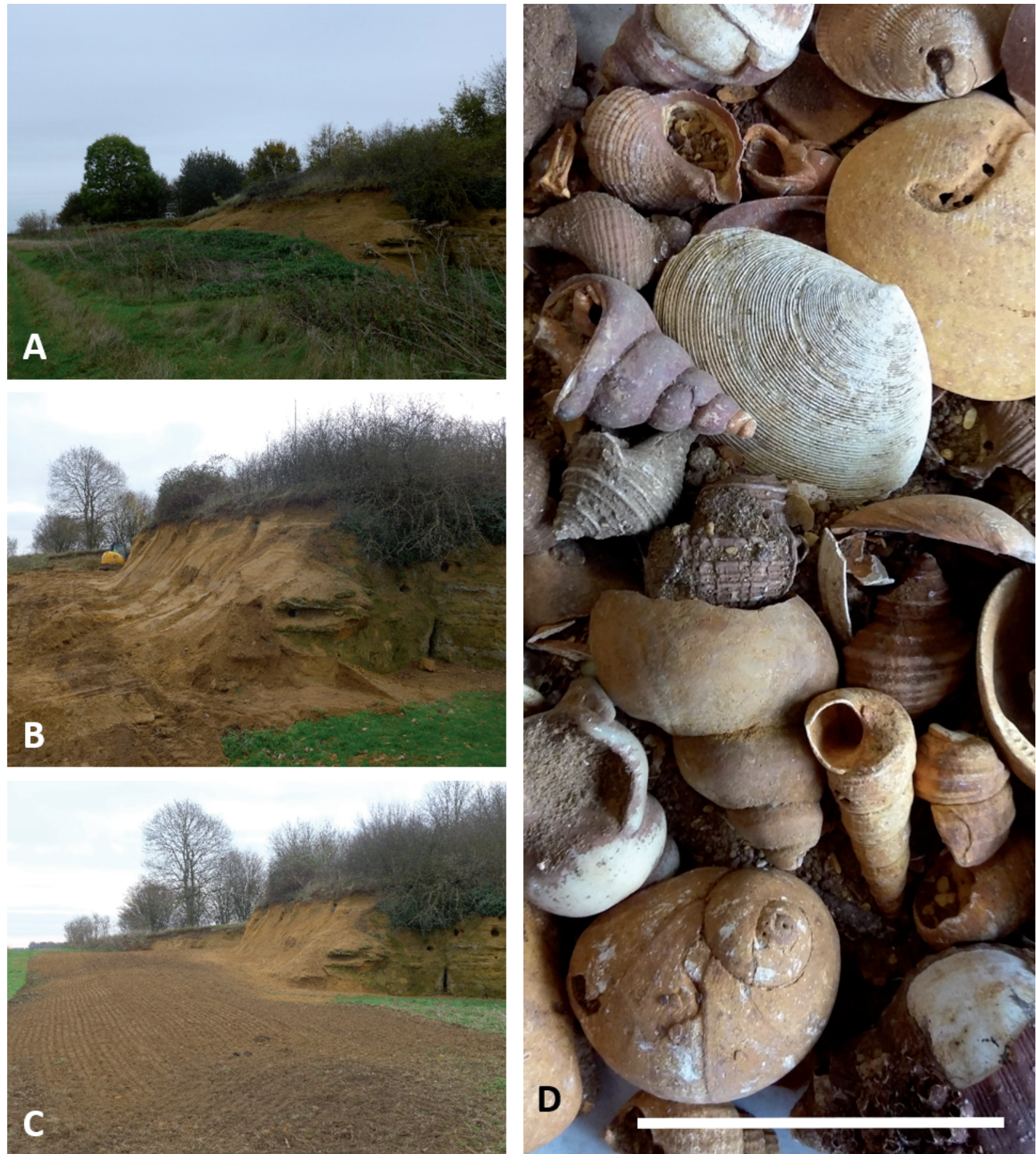

Figure 3. a-c) Before, during and after clearance and re-excavation of the north face of Sutton Knoll (Rockhall Wood SSSI) re-exposing the Pliocene Coralline Crag. (Photographs: Barry Hall). d) Typical Pleistocene Red Crag fossil fauna dominated by marine gastropods and bivalves. Scale bar $=5 \mathrm{~cm}$. (Photograph: Jonathan Larwood).

understand the extent and nature of the fossil resource, its renewability, and the vulnerability to and likely pressure from collecting. Three broad approaches (all of which assume responsible fossil collecting principles are being followed) have been developed to help guide decisions on collecting management (Townley \& Larwood, 2012b):
- Open collecting - this is most appropriate where the fossil resource is extensive and regularly renewed, and can accommodate a range of collecting activity, but always following the responsible collecting principles. Typically, an eroding coast would fall into this category. 
This is illustrated at Charmouth, on the Dorset Coast (Fig. 2). This rapidly eroding coastline (part of the Jurassic Coast WHS) has been popular with collectors since the time of Mary Anning. Famous for its abundant fossil invertebrates, it is also a rich source of Lower Jurassic reptiles, fish and insects. There is high collecting pressure, however, the rapidly eroding coastline with extensive landslips ensures that the fossil resource is continually renewed. Responsible collecting is widely promoted (open collecting) and a West Dorset Collecting Code, including recording scheme for scientifically important fossils, (Fig. 2b) has also been successfully adopted (see: www.charmouth. org/chcc/the-fossil-collecting-code and Townley \& Larwood, 2012c).

- Open-managed collecting - where the fossil resource is restricted in extent and therefore potentially vulnerable to collecting. Here, additional management may be needed. For example, a site-specific code of practice, setting out where collecting is more restricted, or limited only to loose material. Typically, a disused quarry may fall into this category.

Wren's Nest NNR, West Midlands, illustrates open-managed collecting (Fig. 4). Famous for its Silurian reefs and abundant, well preserved, marine invertebrate fauna, most notably trilobites and crinoids, it comprises a network of former limestone quarries and mines cut into the Silurian Much Wenlock Limestone Formation. The fossil resource is limited in extent and only renewed by natural weathering now that quarrying has stopped. Located in an urban setting, the site is open to the public, but has collecting limited to loose material only (use of hammers and in situ collecting requires permission). There are on-site wardens to manage the NNR, encourage responsible collecting and to provide advice to visitors (Prosser \& Larwood, 2008; Townley \& Larwood, 2012d).

- Controlled collecting - recommended where the fossil resource is clearly finite and easily damaged or removed by collecting. Here, access is often controlled, collecting may be restricted to research purposes only, and site wardening may be important. Horn Park NNR, Dorset illustrates this type of collecting. Here, the remnants of a small disused quarry cuts through one of the most famous and richly fossiliferous localities in the Middle Jurassic Inferior Oolite Formation. The fossil resource is extremely finite (c. $0.3 \mathrm{ha}$ ) and vulnerable to collecting due to the high quality of preservation (particularly ammonites). To manage this risk, access is by permission only, the NNR is securely fenced, and in situ collecting is only allowed for bona fide research purposes (Larwood \& Chandler, 2016).
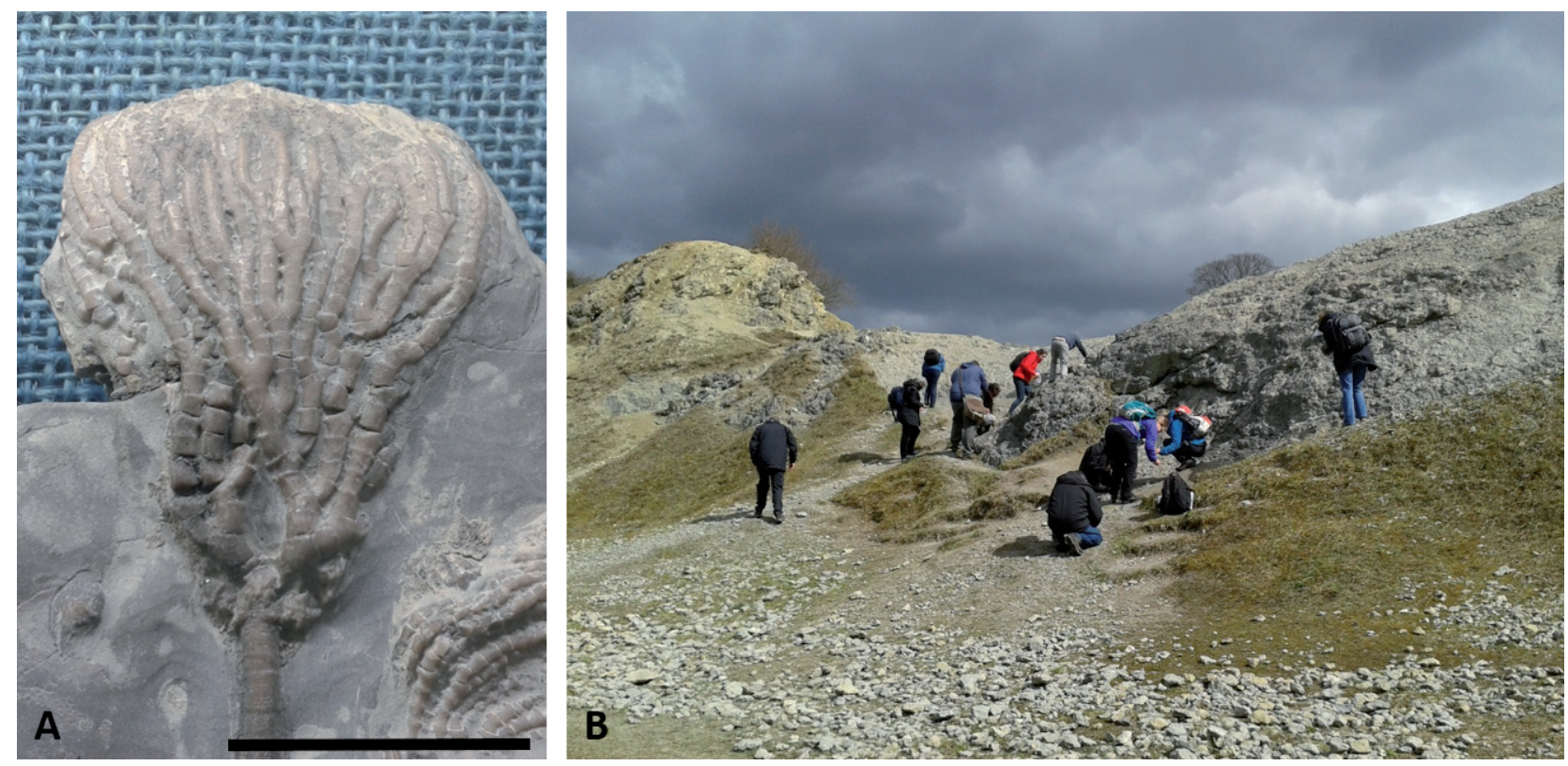

Figure 4. a) The crinoid Gissocrinus goniodactylus from the Silurian Much Wenlock Limestone of the Wren's Nest NNR, Dudley. Well preserved, complete and articulated crinoids are associated with the diverse reef fauna which has over 600 recorded species characterised by trilobites, crinoids, corals, bryozoa, and brachiopods. Scale bar = $10 \mathrm{~cm}$. b) Collecting from the in situ Silurian reef knolls at the Wren's Nest NNR. An example of open-managed collecting which is restricted to loose scree material. (Photographs: Jonathan Larwood). 
Effective palaeontological conservation often requires that the principles and practice set out above are applied in conjunction with the planning system. For example, at Frogden Quarry (discussed above), a controlled collecting approach has been established through the legislative route of a planning agreement. It is also often the case that, where open collecting is supported, the site may also have places where there are more specific (open-managed) collecting requirements. For example, at Charmouth, where the coastline is open to the public to collect responsibly, but there is also a collecting code that restricts collecting on the cliffs and encourages the reporting of scientifically important specimens.

Overall, with the current resources available to support palaeontological conservation, this approach, which balances the application of legislation and advocacy of good collecting practice, has proved an effective and collaborative way of conserving palaeontological sites.

\section{CONCLUSIONS}

The UK has a rich and valued palaeontological heritage recognised since the late eighteenth century. The first examples of active conservation of palaeontological sites date from the late nineteenth century, with comprehensive legislative protection being established by the midtwentieth century.

Palaeontological sites (and collecting) are protected and managed through a mix of nature conservation and planning legislation, agreed management, and the promotion of good collecting practice. The examples referenced here illustrate how these principles have been and are currently being applied. Important throughout, however, is the establishment of an open and trusted relationship between collector, land owner and manager, researcher and museum: with this relationship comes responsible and sustainable collecting, and the sharing of knowledge and discovery to facilitate learning and research.

\section{ACKNOWLEDGEMENTS}

We are grateful to Dr Esperanza Fernández Martínez and the Spanish Journal of Palaeontology for inviting this contribution and collaboration in this monograph issue on palaeontological heritage, and for the guidance and support provided in the completion of this manuscript. Bob Chandler is thanked for the provision of photographs and advice on captions for Frogden Quarry SSSI, Richard Edmonds for Lyme Regis photographs (Fig. 2a), and Phil Davidson for supporting information on the Charmouth brittle star fossil (Fig. 2b).

\section{REFERENCES}

Bassett, M.G., King, A.H., Larwood, J.G., Parkinson, N.A. \& Deisler, V.K. 2001. A future for fossils. National Museum of Wales Geological Series, 19, $156 \mathrm{pp}$.

Brown, E.J., Evans, D.H., Larwood, J.G., Prosser, C.D. \& Townley, H.C. 2018. Geoconservation and geoscience in England: a mutually beneficial relationship. Proceedings of the Geologists' Association, 129, 492-504.

Chandler, R.B., Whicher, J., Dodge, M. \& Dietzr, V. 2014. Revision of the stratigraphy of the Inferior Oolite at Frogden Quarry, Oborne, Dorset, UK. Neues Jahrbuch für Geologie und Paläontologie, 274, 133-148.

Crowther, P.R. \& Wimbledon, W.A. 1988. The use and conservation of palaeontological sites. Special Papers in Palaeontology, 40, 200 pp.

Ellis, N.V., Bowen, D.Q., Campbell, S., Knill, J.L., McKirdy, A.P., Prosser, C.D., Vincent, M.A. \& Wilson, R.C.L. 1996. An Introduction to the Geological Conservation Review. GCR Series No. 1 Joint Nature Conservation Committee, Peterborough, $131 \mathrm{pp}$.

Ellis, N.V. 2011. The Geological Conservation Review (GCR) in Great Britain - rationale and methods. Proceedings of the Geologists' Association, 122, 353-362.

Evans, D. 2010. Trackways partnership triumph. Earth Heritage, 35, 12-13.

Hall, B. 2017. Cleaning the Crags at Sutton Knoll. Earth Heritage, 48, 33-34.

King, A.H. \& Larwood, J.G. 2001. Conserving our most 'fragile' fossil sites in England: the use of 'OLD 25'. In: A Future for Fossils (eds. Bassett, M.G., King, A.H., Larwood, J.G., Parkinson, N.A. \& Deisler, V.K.). National Museum of Wales Geological Series 19, 24-31.

Larwood, J.G. 2010a. Gaining the big picture of Local Geological Sites. Earth Heritage, 35, 6-7.

Larwood, J.G. 2010b. New 'supporting cast' for conservation. Earth Heritage, 35, 11.

Larwood, J.G. \& King, A.H. 2001. Conserving palaeontological sites: applying principles of sustainable development. In: A Future for Fossils (eds. Bassett, M.G., King, A.H., Larwood, J.G., Parkinson, N.A. \& Deisler, V.K.). National Museum of Wales Geological Series 19, 119-125.

Larwood, J.G. \& Markham, D. 1995. Roads and Geological Conservation: a Discussion Document. Peterborough, English Nature, 28pp.

Larwood, J.G \& Chandler, R.B. 2016. Conserving classic geological sections in the Inferior Oolite Formation, Middle Jurassic of the Wessex Basin, south-west England. Proceedings of the Geologists' Association, 127, 132-145.

Noè, L.F., Gómez-Pérez, M. \& Nicholls, R. in press. Mary Anning, Alfred Nicholson Leeds and Steve Etches. Comparing the three most important 'amateur' collectors and their collections. Proceedings of the Geologists' Association; doi: 10.1016/j.pgeola.2018.09.001.

Norman, D.B. 1992. Fossil collecting and site conservation in Britain: are they reconcilable? Palaeontology, 35, 247-256.

Page, K.N. 2018. Fossils, heritage and conservation: managing demands on a precious resource. In: Geoheritage: 
Assessment, Protection and Management (eds. Reynard, E. \& Brilha, J.,). Elsevier, 107-128.

Phillips, J. 1844. Memoirs of William Smith LLD. John Murray, London 150pp.

ProGEO 2011. Conserving our Shared Geoheritage - a Protocol on Geoconservation Principles, Sustainable Site Use, Management, Fieldwork, Fossil and Mineral Collecting. ProGEO, 10pp.

Prosser, C.D. 2008. The history of geoconservation in England: legislative and policy milestones. In: The History of Geoconservation (eds. Burek, C.V. \& Prosser, C.D.). The Geological Society, London, Special Publications, 300, 113-122.

Prosser, C.D. 2010. Henry Clifton Sorby: a founder of geoconservation? Geology Today, 26, 45-46.

Prosser, C.D. 2013. Planning for geoconservation in the 1940s: an exploration of the aspirations that shaped the first national geoconservation legislation. Proceedings of the Geologists' Association, 124, 536-546.

Prosser, C.D. \& Larwood, J.G. 2008. Conservation at the cutting edge: the history of geoconservation on the Wren's Nest National Nature Reserve, Dudley, England. In: The History of Geoconservation (eds. Burek, C.V. \& Prosser, C.D.). Geological Society, London, Special Publications, 300, 217-235.

Prosser, C.D., Murphy, M. \& Larwood, J.G. 2006. Geological Conservation: a guide to good practice. English Nature, Peterborough. Available from: http://publications. naturalengland.org.uk/publication/83048? category $=30050$.

Prosser, C.D., Díaz-Martínez, E. \& Larwood, J.G. 2018. The conservation of geosites: principles and practice. In: Geoheritage: Assessment, Protection and Management (eds. Reynard, E. \& Brilha, J.). Elsevier, 191-212.

Rudwick, M.J.S. 1976. The Meaning of Fossils: Episodes in the History of Palaeontology. $2^{\text {nd }}$ edition. Science and History Books, New York, 287pp.

Sorby, H.C. 1875. On the remains of a fossil forest in the coalmeasures at Wadsley, near Sheffield. Quarterly Journal of the Geological Society of London, 31, 458-460.

Taylor, M.A. \& Harte, J.D.G. 1991. The local geologist: fossils, minerals and the law. Geology Today, 7, 189-193.
Thomas, B.A. 2005. The palaeobotanical beginnings of geological conservation: with case studies from the USA, Canada and Great Britain. In: History of Palaeobotany: Selected Essays (eds. Bowden, A.J., Burek, C.V. \& Wilding, J.). The Geological Society of London, Special Publications, 241, 95-110.

Torrens, H.S. 1995. Mary Anning (1799-1847) of Lyme; 'the greatest fossilist the world ever knew'. The British Journal for the History of Science, 28, 257-284.

Townley, H. \& Larwood, J.G., 2012a. Managing geological specimen collecting: responsible collecting. Natural England Technical Information Note TIN 112, Natural England, Peterborough. Available from: http://www. englishgeodiversityforum.org/casestudies.html.

Townley, H. \& Larwood, J.G. 2012b. Managing geological specimen collecting: guidance. Natural England Technical Information Note TIN 111, Natural England, Peterborough. Available from: http://www.englishgeodiversityforum.org/ casestudies.html.

Townley, H. \& Larwood, J.G. 2012c. Managing geological specimen collecting: Charmouth case study. Natural England Technical Information Note TIN 114, Natural England, Peterborough. Available from: http://www. englishgeodiversityforum.org/casestudies.html.

Townley, H. \& Larwood, J.G., 2012d. Managing geological specimen collecting: Wren's Nest case study. Natural England Technical Information Note TIN 118, Natural England, Peterborough. Available from: http://www. englishgeodiversityforum.org/casestudies.html.

Whiteley, M.J. \& Browne, M.A.E. 2013. Local geoconservation groups - past achievements and future challenges. Proceedings of the Geologists' Association, 124, 674-680.

Williams, D. \& Edwards, D. 2013. Moulding and cast replication of outcrops: a tool in geoconservation, Proceedings of the Geologists' Association, 124, 648-652.

Wimbledon, W.A.P. \& Smith-Meyer, S. 2012. Conserving our shared geoheritage. In: Geoheritage in Europe and its Conservation (eds. Wimbledon, W.A.P. \& Smith-Meyer, S.). ProGEO, 14-20. 